\title{
APPLICATION OF SELECTED METHODS AND APPROACHES FOR IMPROVEMENT OF PROCESSES AND THEIR USE IN PRACTICE IN COMPANIES OF WOOD PROCESSING INDUSTRY IN SLOVAKIA
}

\author{
L'ubica SIMANOVÁ, Pavol GEJDOŠ \\ Technical university in Zvolen
}

\begin{abstract}
:
The aim of the paper is to point out the principles of process management and selected quality management tools, which are aimed at improving the processes of the wood processing industries of the Slovak Republic. The knowledge from these areas is based on the analysis of the theoretical origins from domestic and foreign sources and supported by the results of the research carried out in the first half of the year 2017. In the processing of the results, classical methods of research work were used such as analysis, synthesis, comparison, descriptive statistics, contingency tables, chi-quadrat test and graphic depiction. Based on the analysis of the research results, there was a slight dependence between the process optimization levels in the timber industry and other process improvement methods such as statistical process control methods and graphical analysis and problem solving tools.
\end{abstract}

Key words: process, process management, process improving, quality management methods

\section{INTRODUCTION}

Managers of business entities are forced to constantly look for new methods and concepts that bring a new approach to traditional management approaches to process management approaches. The decisive factor for competitive advantage, success, business flexibility and stability of the business entity is their focus on the process approach to management. Although this approach is not new, its advantages are now appreciated in comparison with the functional approach. In particular, it is the implementation of new concepts and methods aimed at improving, optimizing and modelling the processes the use of which is presented in the article. The expected result is new capabilities to increase process performance and thereby increase the competitiveness of enterprises as a whole.

\section{MATERIAL AND METHODS}

The Pivot Table is a method of organizing and analysing data by groups, categories, or classes that allows you to compare them. It combines the division of the two variables and represents the extension of a simple frequency table [16]. To determine statistical dependencies, the Pearson Chi-quadrate test was used as the most common test of relevance of the relationship between qualitative variables. The authors define the process, such that the process must have inputs and outputs, must have logical continuity, must contain added value, must have a customer, whether internal or external, must have a process owner and must be repeatable and measurable $[3,8,13,20]$. The process is closely related to process management and was defined by various authors. The authors agree that process-driven organizations are customer-centred, create higher value for the customer, focus on process management through analyses and metrics, use concepts, methods and approaches to improve processes as well as optimize and model them for to make them more radical changes and improving their performance $[8,15,19]$.

Process improvement is a BPM (Business Process Management) category. Its active role lies in identifying, analysing and improving existing business processes in organizations to optimize and meet new quotes and quality standards, using new concepts, approaches and methods. When investigating the use of concepts and methods to improve processes, we focused on the following methods: BSC (Balanced scorecard) helps to strike a balance between financial and non-financial performance measures, and build up causal links between the leading and lagging performance measures, the short-term and long-term performance measures, and the internal and external performance measures. The BSC has been developed to provide organizations with a comprehensive view of their business model. The BSC features four perspectives (financial, customer, internal processes, learning and growth/innovation), which explains how the strategic objectives of an organization can be attained $[10,11]$.

Six Sigma is a methodology focused on the improvement of manufacturing processes, where product quality is the response variable for all activities. The aim of Six Sigma is to 
produce no more than 3.4 defects per million opportunities, making it an appealing proposition for production managers. This is perhaps the most important definition of Six Sigma as a methodology, since it implies that processes must be appropriately standardized [12, 17, 22]. Process controlling is used to ensure process management and is part of corporate controlling focused on planning, controlling, optimizing, and evaluating processes at all levels of business activities. The reasons for introducing process controlling into corporate practice are primarily to provide better insight into business activities and processes, measure unit cost of processes, and rationalize cost savings to optimize them $[5,14]$.

Kaizen means continuous process of improvement which engages top management of a company, management staff and all employees. It requires relevant changes in people's behaviour and authority based on experience, authority of leader. Kaizen is a structured, iterative and participatory approach for making continuous improvement. In Kaizen, one of the main reasons for engaging employees in continuous improvement is the assumption that the people closest to the work process are best suited to quickly identify areas in need of improvement and, consequently, implement action plans [6, 9].

Total Quality management TQM is characterized as a strategy that aims to generate and transfer more efficient and superior services, through achieving cooperation between organisational members achieve a comprehensive integration among organisational staff and their functions in order to gain better enhancement, progress and preservation of products and services quality to achieve customer satisfaction, applying various TQM practices such as training, process management, customer management, etc. influence employees that performance which then directly affect the whole organisation performance, especially in their financial performance $[2,7,21]$.

Benchmarking is the continual and collaborative discipline of measuring and comparing the results of key work processes with those of the best performers. It is learning how to adapt these best practices to achieve breakthrough process improvements and build healthier communities. The term benchmarking emerged within the context of comparison process. Subsequently, and without necessarily any continuity, the concept of benchmarking became more tightly defined as referring to the analysis of processes and of success factors for producing higher levels of performance $[1,4,23]$.

\section{RESULTS AND DISCUSSION}

The aim of the paper is to present the results of the questionnaire survey, which investigated the extent of utilization of modern concepts and methods used for improvement, optimization and modelling of processes in 82 wood processing enterprises (WPI) in Slovakia. Primary data was obtained through standardized questionnaires and complemented by a qualitative survey through interviews with business executives. Research was conducted in the first half of the year 2017. The data obtained by the questionnaire method were processed into tables and graphs using the program STATISTICA 12 CZ - Stat Soft. Inc. 2013 [18].
Analysis of monitored and improved processes in WPI enterprises

In researching the use of concepts and methods for process improvement and monitoring, attention was focused on the breakdown of processes by focus. The highest percentages of $76.83 \%$ were obtained in response to a question related to monitoring and process improvement in WPI enterprises that are predominantly manufacturing.Monitoring and improvement of purchasing and supply processes reached $53.66 \%$, logistics processes $35.37 \%$ and innovation processes $20.73 \% .15 .85 \%$ of WPI enterprises monitor nonprofit service processes, and in $10.98 \%$ of WPI enterprises marketing processes and CRM processes. The lowest percentages of $1.22 \%$ were achieved in response to the fact that WPI enterprises do not periodically evaluate or even improve their processes. The results are shown in Figure 1.

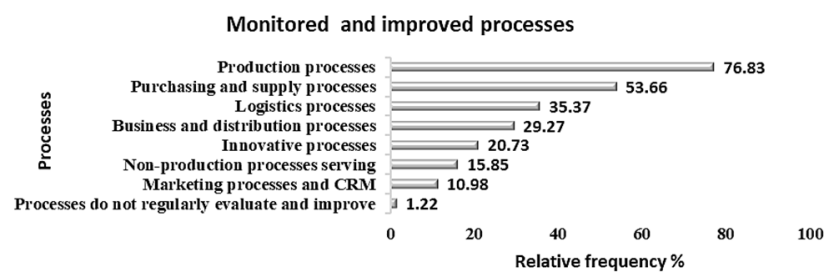

Fig. 1 Analysis of monitored and improved processes in WPI enterprises

Source: personal processing according to results of projects No. 1/0286/16.

Out of the answers to the question of using process concepts and methods, the answer that businesses do not use any of the methods and concepts to improve processes received the highest percentages. These responses occurred in $69.51 \%$ of WPI enterprises. Kaizen (continuous improvement of business processes) and process controlling is used in WPI enterprises from $10.98 \%$ to $12.21 \%$. When using benchmarking and TQM, lower percentages were recorded in WPI enterprises, ranging from $2.44 \%$ to $4.88 \%$. The Balanced Scorecard (BSC) and the Six Sigma concept use all WPI enterprises at $2.44 \%$. Other concepts and methods are used in $1.22 \%$ of WPI enterprises. The results of the above questionnaire survey are shown in Figure 2.

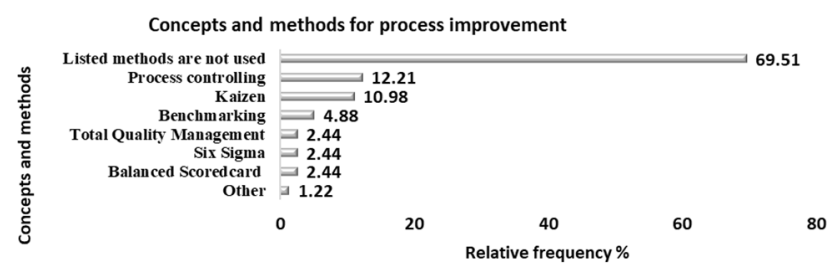

Fig. 2 Concepts and methods used to improve processes in WPI enterprises

Source: personal processing according to results of projects No. $1 / 0286 / 16$.

Analysis of the relationship between the level of process optimization and the use of concepts and methods to improve processes

From the data shown in Table 1, it can be seen that WPI enterprises ranging from $77.80 \%$ to $100 \%$ for each category of process optimization level do not use any of these concepts. The overall frequency of responses to this question is $47.47 \%$ for WPI enterprises. The most frequent answer was the use of process controlling with a relative frequency 
of $16.16 \%$. On the other hand, the least used new concept is based on the results of Six Sigma and BSC, the frequency of which reaches less than $4.1 \%$ of responses.

Table 1

The contingency of the level of optimization (improvement) of processes and the use of new concepts and methods Level of process optimization
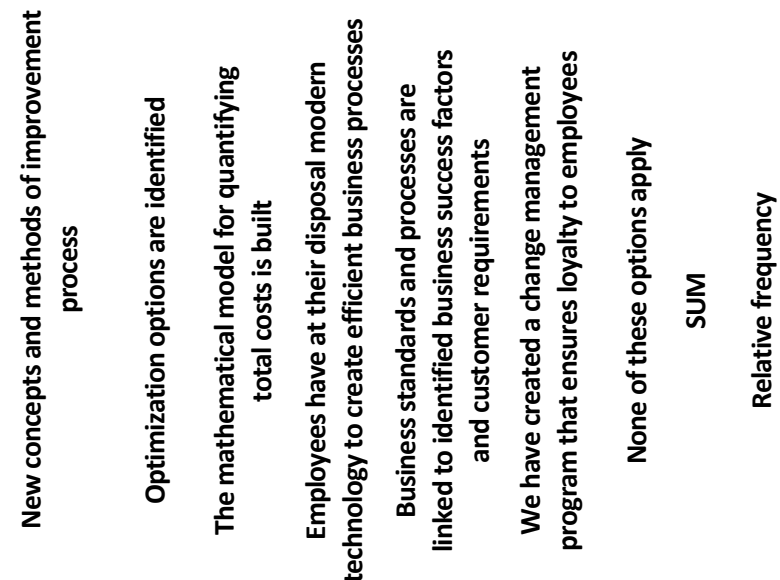

\begin{tabular}{|c|c|c|c|c|c|c|c|}
\hline BSC & $\begin{array}{c}4 \\
8.89 \%\end{array}$ & $0.00 \%$ & $0.00 \%$ & $0.00 \%$ & $0.00 \%$ & $0.00 \%$ & 4.0 \\
\hline Si & 1 & 0 & 0 & 1 & 1 & 0 & \\
\hline Sigma & $2.22 \%$ & $0.00 \%$ & $0.00 \%$ & $11.11 \%$ & $11.11 \%$ & $0.00 \%$ & \\
\hline PC & $\begin{array}{c}11 \\
24.44 \%\end{array}$ & $\begin{array}{c}0 \\
0.00 \%\end{array}$ & $\begin{array}{c}0 \\
0.00 \%\end{array}$ & $\begin{array}{c}2 \\
22.22 \%\end{array}$ & $\begin{array}{c}3 \\
33.33 \%\end{array}$ & $\begin{array}{c}0 \\
0.00 \%\end{array}$ & \\
\hline TQN & $\begin{array}{c}4 \\
8.89 \%\end{array}$ & $\begin{array}{c}0 \\
0.00 \%\end{array}$ & $\begin{array}{c}1 \\
12.50 \%\end{array}$ & $\begin{array}{c}3 \\
33.33 \%\end{array}$ & $\begin{array}{c}1 \\
11.11 \%\end{array}$ & $\begin{array}{c}0 \\
0.00 \%\end{array}$ & $9.09 \%$ \\
\hline$K_{z}$ & $\begin{array}{c}7 \\
15.55 \%\end{array}$ & $\begin{array}{c}0 \\
0.00 \%\end{array}$ & $\begin{array}{c}1 \\
12.50 \%\end{array}$ & $\begin{array}{c}1 \\
11.11 \%\end{array}$ & $\begin{array}{c}1 \\
11.11 \%\end{array}$ & $\begin{array}{c}0 \\
0.00 \%\end{array}$ & \\
\hline $\begin{array}{l}\text { Bench- } \\
\text { marking }\end{array}$ & $\begin{array}{c}3 \\
6.67 \%\end{array}$ & $\begin{array}{c}1 \\
100 \%\end{array}$ & $\begin{array}{c}1 \\
12.50 \%\end{array}$ & $\begin{array}{c}3 \\
33.33 \%\end{array}$ & $\begin{array}{c}1 \\
11.11 \%\end{array}$ & $\begin{array}{c}0 \\
0.00 \%\end{array}$ & $9.09 \%$ \\
\hline $\mathbf{N}$ & 17 & 0 & 10 & $\begin{array}{c}7 \\
778\end{array}$ & $\begin{array}{l}1 \\
1.11\end{array}$ & 13 & \\
\hline
\end{tabular}

Source: personal processing according to results of projects No. $1 / 0286 / 16$.

Abbreviations used in Table 1: Balanced Scorecard (BS), Six Sigma (SS), Process controlling (PC), Total Quality Management (TQM), Kaizen (K), Benchmarking (B), We do not use any of these methods and concepts $(\mathrm{N})$.

Table 2 analyses the relationship between the level of process optimization and the use of enterprise process modelling tools in WPI enterprises. When analysing the "Others" response, it was stated at each level of process optimization that businesses use other process modelling tools as mentioned in the research questionnaire. The most responsive representation of the percentage of responses is the "none of these options" answer group. This was reported by up to $90 \%$ of WPI enterprises. These businesses use other process modelling tools such as Business Process Modelling, Supply Chain Management, and Enterprise Resource Planning.

Before analysing the results presented in Table 3, a zero hypothesis was required: $\mathrm{HO}$ : There is no relationship between the level of optimization WPI enterprises and the use of other concepts and methods for process improvement.
Table 2

The contingency level of process improvement and tool for business process modelling Level of process optimization

\begin{tabular}{|c|c|c|c|c|c|c|c|}
\hline 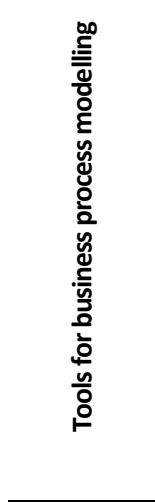 & 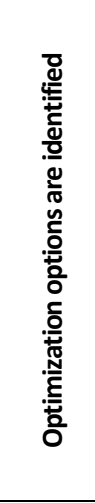 & 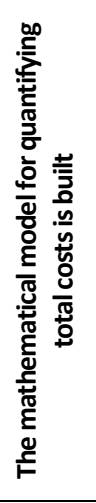 & 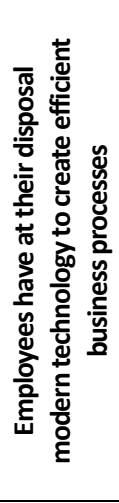 & 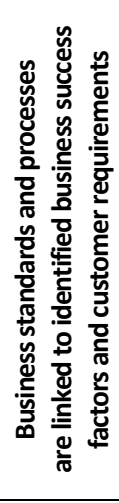 & 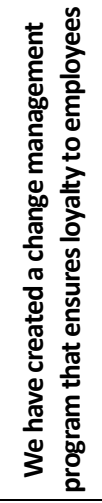 & 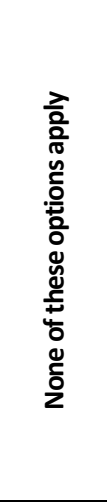 & 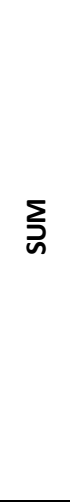 \\
\hline p & $\begin{array}{c}6 \\
13.33 \%\end{array}$ & $\begin{array}{c}0 \\
0.00 \%\end{array}$ & $\begin{array}{c}2 \\
2.00 \%\end{array}$ & $\begin{array}{c}1 \\
11.11 \%\end{array}$ & $\begin{array}{c}3 \\
33.33 \%\end{array}$ & $\begin{array}{c}0 \\
0.00 \%\end{array}$ & 12 \\
\hline $\begin{array}{l}\text { Data Flow } \\
\text { Diagram }\end{array}$ & $\begin{array}{c}2 \\
4.44 \%\end{array}$ & $\begin{array}{c}0 \\
0.00 \%\end{array}$ & $\begin{array}{c}0 \\
0.00 \%\end{array}$ & $\begin{array}{c}0 \\
0.00 \%\end{array}$ & $\begin{array}{c}0 \\
0.00 \%\end{array}$ & $\begin{array}{c}0 \\
0.00 \%\end{array}$ & 2 \\
\hline Flow chart & $\begin{array}{c}1 \\
2.22 \%\end{array}$ & $\begin{array}{c}1 \\
100 \%\end{array}$ & $\begin{array}{c}1 \\
12.50 \%\end{array}$ & $\begin{array}{c}0 \\
0.00 \%\end{array}$ & $\begin{array}{c}0 \\
0.00 \%\end{array}$ & $\begin{array}{c}0 \\
0.00 \%\end{array}$ & 3 \\
\hline $\begin{array}{l}\text { Petri net- } \\
\text { work }\end{array}$ & $\begin{array}{c}0 \\
0.00 \%\end{array}$ & $\begin{array}{c}0 \\
0.00 \%\end{array}$ & $\begin{array}{c}0 \\
0.00 \%\end{array}$ & $\begin{array}{c}1 \\
11.11 \%\end{array}$ & $\begin{array}{c}0 \\
0.00 \%\end{array}$ & $\begin{array}{c}0 \\
0.00 \%\end{array}$ & 1 \\
\hline $\begin{array}{l}\text { Object Inter- } \\
\text { action Dia- } \\
\text { gram }\end{array}$ & $\begin{array}{c}0 \\
0.00 \%\end{array}$ & $\begin{array}{c}1 \\
100 \%\end{array}$ & $\begin{array}{c}0 \\
0.00 \%\end{array}$ & $\begin{array}{c}0 \\
0.00 \%\end{array}$ & $\begin{array}{c}0 \\
0.00 \%\end{array}$ & $\begin{array}{c}0 \\
0.00 \%\end{array}$ & 1 \\
\hline Other & $\begin{array}{c}36 \\
80.00 \%\end{array}$ & $\begin{array}{c}0 \\
0.00 \%\end{array}$ & $\begin{array}{c}6 \\
75.00 \%\end{array}$ & $\begin{array}{c}7 \\
77.78 \%\end{array}$ & $\begin{array}{c}6 \\
66.67 \%\end{array}$ & $\begin{array}{c}9 \\
90.00 \%\end{array}$ & 64 \\
\hline $\begin{array}{l}\text { We do not } \\
\text { use any tool }\end{array}$ & $\begin{array}{c}2 \\
4.44 \%\end{array}$ & $\begin{array}{c}0 \\
0.00 \%\end{array}$ & $\begin{array}{c}0 \\
0.00 \%\end{array}$ & $\begin{array}{c}0 \\
0.00 \%\end{array}$ & $\begin{array}{c}0 \\
0.00 \%\end{array}$ & $\begin{array}{c}1 \\
10.00 \%\end{array}$ & 3 \\
\hline SUM & 47 & 2 & 9 & 9 & 9 & 10 & 86 \\
\hline $\begin{array}{c}\text { Relative fre- } \\
\text { quency }\end{array}$ & $54.65 \%$ & $2.33 \%$ & $10.47 \%$ & $10.47 \%$ & $10.47 \%$ & $11.63 \%$ & $100 \%$ \\
\hline
\end{tabular}

Table 3

Results of Chi-square test for a relationship between the level of optimization in WPI enterprises and the answer "Other"

\begin{tabular}{cccc}
\hline & Chi-square & $\begin{array}{c}\text { Degree of } \\
\text { freedom }\end{array}$ & Value $\mathbf{p}$ \\
\hline Pearson Chi-square & 39.05747633 & 5 & $\mathbf{0 . 0 1 6 8 0 6 5 4 5}$ \\
Correlation coefficient & 0.98545577 & & \\
Cramer - V & 0.29964529 & & \\
\hline
\end{tabular}

The results in Table 3 confirmed the dependence between the level of process optimization and whether WPI enterprises also used other concepts and methods than proposed. On the basis of Cramer's $-V$ measuring of relations was possible to conclude that the strength relationship was 0.299 and is thus the slight relationship over 0.29 and under 0.59 . The correlation coefficient is 0.985 , it is a positive dependence and the $p$ value is 0.0168 , which is less than 0.05 , and confirms the statistical significance of the question. Cramer - $\mathrm{V}$ talks about a moderate connection between the implementation of other methods and concepts and the level of process optimization in WPI enterprises. Based on the above results, the $\mathrm{HO}$ hypothesis was rejected: there is no relationship between the level of process optimization in WPI enterprises and the use of other concepts and methods to improve the processes of moderate dependency. 
In conclusion, we can conclude from the analysis of research results that there has been a slight dependence between process optimization levels in the woodworking industry and other process improvement methods such as process control statistical methods and graphical analysis and troubleshooting tools. Business process modelling, Supply chain management and Enterprise resource planning have responded to up to $90 \%$ of businesses, of which about $10 \%$ have reported the use of these modelling tools and others have not reported any other method or tool.

\section{CONCLUSION}

At present, each enterprise has to adapt effectively to changes in the market and customer requirements. It is important to realize that an enterprise needs to optimize and improve its processes every day, otherwise it is in danger of extinction. Improving the quality of products, processes and the harmonious course of business activities can be achieved through the right selection and systematic use of new concepts, approaches and methods of quality improvement. The main aim of the contribution was to characterize the selected concepts and methods on the basis of the theoretical knowledge from domestic and foreign sources, based on the results of questionnaire research to illustrate the use of these concepts and methods in enterprises of the wood processing industry of the Slovak Republic. As outlined in questionnaire research, businesses of the above categories use at least one of the concepts, approaches and methods offered. If their choice, implementation, and application in the processes of improvement, monitoring and modelling are correct, it will ensure that the enterprise streamlines processes, long-term prosperity and market stability, not excluding long-term competitiveness. The research results will be used for further research in the area of process optimization, improvement and modelling over a broader time frame and their development will be compared.

\section{ACKNOWLEDGEMENT}

This paper is the partial result of the projects No. 11TU Z4/2017 under KEGA agency, Slovakia.

\section{REFERENCES}

[1] R. Bayney, Benchmarking in mental health: an introduction for psychiatrists. Adv Psychiatr Treat, 2005, pp. 305-314.

[2] A. Brun. Critical success factors of six sigma implementation in Italian companies.International Journal of Production Economics, 2010, pp. 1-7.

[3] J. Cienciala. Process-managed organization: process creation, development and measurability. Prague: Professional Publishing, 2011, pp. 204.
[4] J. Ellis. All Inclusive Benchmarking. Journal of Nursing Management. 2006, pp. 377-383.

[5] R. Eschenbach, Controlling. Praha: ASPI, 2004, pp. 814.

[6] J. Frąś. Total quality management in logistics. Poznań: Wyd. Wyższej Szkoły Logistyki w Poznaniu. 2013, pp. 382.

[7] D. Gharakhani, H. Rahmati, M. Farrokhi, A. Farahmandian. Total Quality Management and Organizational Performance, American Journal of Industrial Engineering, Vol. 1, No. 3, 2013, pp. 4650. DOI: 10.12691/ajie-1-3-2

[8] M. Grasseová, R. Dubec and R. Horák. Process management in the public sector: theoretical background and practical examples. Brno: Computer Press, 2008, pp. 266.

[9] G. Jacobson, N. McCoin, R. Lescallette, S. Russ, C Slovis. Kaizen: A method of process improvement in the emergency department. Academy Emergency Medicine 16 (12): 2009, pp. 13411349.

[10] Z. Lin, Z. Yu, L. Zhang, Performance outcomes of balanced scorecard application in hospital administration in China. China Economic Review 30, 2014, pp. 1-15.

[11] R. Lueg, Strategy maps: the essential link between the balanced scorecard and action. Journal of Business Strategy 36, 2015. pp. 34-40.

[12] P. M. Madhani. Six Sigma Deployment in Sales and Marketing: Enhancing Competitive Advantages. IUP J. Bus. Strategy, 2017, p. 40-63.

[13] K. Marcineková, A. Sujová. The influence of the process control level on the enterprises' roe. Conference: 9th ISCBEM. Book Series: Economics and Finance. No: 34. 2015, pp. 290-295.

[14] M. Messner, A. Becker, U. Schaeffer, and C. Binder. Legitimacy and Identity in Germanic Management Accounting Research. European Accounting Review, 17, 2008, pp. 129-159.

[15] Z. Papulová, J. Papula and A. Oborilová, Process Management. A comprehensive view of the process management concept. Bratislava: Kartprint, 2014, pp. 223.

[16] M. Rimarčík. Statistics for practice. Košice: Médium, 2007, pp. 200.

[17] S. Shaaban, A.S. Darwish. Production Systems: Successful applications and new challenges part one-Lean, six sigma, inventory, JIT and TOC. Prod. Plan. Control, 2016, pp. 539-540.

[18] Stat Soft. Inc. (2013). STATISTICA (data analysis software system), version 12. www.statsoft.com

[19] E. Sujová, H. Čierna. Optimization and improvement of test processes on a production line. In Management systems in production engineering. Vol. 26, 2018, pp. 88-92.

[20] A. Svozilová. Improving business processes. Prague: Grada, 2011, pp. 232.

[21] F. Talib. An overview of total quality management: understanding the fundamentals in service organization, International Journal of Advanced Quality Management, Volume 1, Issue 1, 2013, pp. 1-20.

[22] D. Tlapa, J. Limon, J.L. García-Alcaraz, Y. Baez, C. Sánchez. Six sigma enablers in Mexican manufacturing companies: A proposed model. Ind. Manag. Data Syst. 2016, pp. 926-959.

[23] W.A.M. Van Lent, R.D. de Beer, W.H van Harten. International benchmarking of specialty hospitals. A series of case studies on comprehensive cancer centres. BMC Health Serv Res.2010, pp 253.

\section{Pavol Gejdoš}

Technical university in Zvolen

Faculty of Wood Sciences and Technology

Department of Economics, Management and Business

T. G. Masaryk 2117/24, 96053 Zvolen, Slovak Republic

e-mail: gejdosp@tuzvo.sk

ORCID ID: 0000-0002-4665-9762 